\title{
SOME REFLECTIONS ON PROFESSOR MALAWSKI'S IDEAS CONCERNING ECONOMICS, MATHEMATICS, AND PHILOSOPHY
}

\section{Abstract}

This paper explores the ways Prof. A. Malawski understood the various kinds of interplay between economics, mathematics, and philosophy. In particular, it addresses the issue of the mathematicity of the economy and what it means for economics to be a mathematical science. Next, it focuses on the nature of economic laws. It concludes by claiming that the interpretative key to Prof. Malawski's research lies in his deep humility.

Keywords: A. Malawski, philosophy of economics, mathematisation of economics, laws and models in economics.

JEL Classification: B40, C18.

\section{Introduction}

I had the privilege of knowing Professor Andrzej Malawski, whom I greatly admired not only for his intellectual capacity but also for his humility and wisdom. He was a truly virtuous man. In his writings he was ambitious and thus conscious that economics as such was not enough to understand the socio-economic world and that researchers should analyse the world in much greater depth; hence his interest in philosophy and the foundations of mathematics. I would say that Prof. Malawski went even further - he not only explored the socio-economic realm but also contemplated it. Consequently, he was well aware that one cannot resolve 
the mystery of the world, although one can still progress towards a better understanding of it. This explains his commitment to philosophical realism. In one of his last texts, he wrote: "I accept what philosophers call ontological and epistemological realism and accordingly that there is an objective reality independent from the researcher that analyses it (...). Our world is characterized by ontological depth" (Malawski 2016, pp. 132-33). Such an attitude probably contributed to his endorsement of Jevons's idea that "(...) economics, if it is to be a science at all, must be a mathematical science" (Jevons 1879, p. 3). Prof. Malawski spent years investigating what precisely being a mathematical science means for economics.

In this article I will not attempt to reconstruct all of Prof. Malawski's ideas in detail, but will rather reflect on some of them. As a philosopher of economics I am particularly interested in Prof. Malawski's work at the intersection of economics, mathematics, and philosophy. Therefore, I am interested in the following issues: (1) to what extent the economic realm can be studied using only mathematical techniques and to what extent socio-economic worlds are ontologically mathematical; or, in other words, are economies mathematical or are they only mathematicised? (2) can mathematics alone, without making any reference to laws, causes etc., explain economic phenomena? (3) the proper understanding of the nature of laws in economics. In analysing these issues I shall refer in particular to Prof. Malawski's inspiring 1999 book entitled The Axiomatic Method in Economics $^{1}$ (Malawski 1999).

\section{Is the Economic World Mathematical or Only Mathematicised?}

As Prof. Malawski was both a mathematician and economist, the question of whether the economic realm was mathematical preoccupied him for years. In his 1999 book, he stated:

Therefore, it is difficult to find arguments for treating the mathematical character of economic reality similarly to the way we conceptualise the mathematical nature of material world (...). Thus, it seems impossible to broaden the hypothesis of the so-called field of rationality from natural world structures towards social ones (...). Consequently, the very fact that economics can be mathematicised does not necessarily mean that economic systems are mathematical (Malawski 1999, p. 166) ${ }^{2}$.

\footnotetext{
${ }^{1}$ For this book, Prof. Malawski was awarded the Bank Handlowy Prize for Particular Achievements in Economics in 2000.

${ }^{2}$ The field of rationality idea was put forward by Józef Życiński. It may be described as "a kind of a formal field constituted by a net of mathematical structures and abstract relations. This
} 
In one of his last texts he still argued against the mathematicity of economic realm:

(...) the extraordinary efficacy of mathematics in explaining the physical world does not translate into an understanding of social life and its economic dimension (...); however, attempts to mathematize economics are not fruitless. They give better insight into the nature of research problems in economics and thus can lead to enhanced prediction of economic phenomena (Malawski 2016, p. 132).

The issue of whether economies are inherently mathematical was raised by some nineteenth century economists. However, since neoclassical economics was conflated relatively soon with mathematical economics, this issue ceased to catch the attention of economic thinkers. Indeed, as P. Mirowski (2012) explains, for decades now, there has been no real debate or contact between the philosophy of mathematics and the philosophy of economics. Nevertheless, we can point to some lines of thought which suggest, on the one hand, that economies are naturally quantitative and, on the other, that mathematics should be treated only as a language in which economics can be rewritten. Those ascribing a mathematical character to the economic realm usually refer in some way to the Putnam-Quine thesis concerning the indispensability of mathematics for the empirical sciences. Let me therefore recall H. Putnam's words:

So far I have been developing an argument for realism along roughly the following lines: quantification over mathematical entities is indispensable for science, both formal and physical; therefore we should accept such quantification; but this commits us to accepting the existence of the mathematical entities in question. This type of argument stems, of course, from Quine, who has for years stressed both the indispensability of quantification over mathematical entities and the intellectual dishonesty of denying the existence of what one daily presupposes (Putnam 1979, p. 347).

However, as recent studies in the philosophy of science show, one can distinguish between the weak and strong indispensability argument (Decock 2002). The former refers to W. V. Quine's thesis that "to be is to be the value of a variable"; thus it only postulates that mathematical variables exist in our theories and that mathematical statements (theorems) are true, yet it says nothing about the realities beyond our theories. The latter, on the other hand, makes a stronger ontological claim and states that only really 
indispensable mathematical objects in our theories are allowed to function as the values of variables. How do such arguments refer to Platonism about mathematics, namely, to the view - put very simply - that mathematical objects are discovered rather than created in theory-making? And here many philosophers treat the Putnam-Quine indispensability argument as the best way of defending Platonism (or mathematical realism). But important problems still remain, for instance, the very meaning of indispensability. I offer some comments on this issue below.

Firstly, what does it mean to be indispensable? If a given entity, say a mathematical one, is dispensable, then after eliminating it our theory should be still acceptable, e.g. it may still provide explanations. In such a case, if what is eliminated is a mathematical entity, then this very entity cannot be characterised as being indispensable. Therefore, one should ask how much mathematics is indispensable (Colyvan 2015). According to Putnam and Quine, the indispensability of mathematics is defined by its ability to have physical designates. In other words, according to Quine, if we do not find physical application of a given mathematical theory, then our mathematics is just "(..) recreation (...) without ontological rights" (Quine 1986, p. 400). But one can claim here that the very fact that one cannot find any physical picture of a given mathematical fact cannot alone support the thesis that this fact is dispensable, since one may be able to find such a physical realm in the future. The history of non-Euclidean geometry and Hilbert's axioms can be illuminative in this context.

Secondly, what would be Prof. Malawski's standpoint in this debate? It is definitely hard to say. However, what I would claim is that he might follow P. Kitcher's (1984) criticism of the indispensability thesis by insisting that the Putnam-Quine argument does not explain why mathematics is indispensable for science and for economics in particular. Hence Prof. Malawski's question of whether the economic realm is ontologically mathematical. As we know, he claimed that economies are not mathematical to the extent that physical worlds are. Also, for both Malawski and Kitcher, questions about the indispensability and ontological status of mathematics are relatively separate. But what about another critique raised against Putnam and Quine, namely, from H. H. Field (1980), who argued that mathematics is not indispensable for science. I think Prof. Malawski would disagree. He put forward a lot of arguments for the efficacy of the axiomatic method in economics. In his 1999 book, he wrote: "It leads to the final conclusion that the axiomatic method in economics is legitimate and that its popularization, being a part of a broader phenomenon in science as such, can be treated as a wide-ranging 
tendency in science, namely, its euclidization" (Malawski 1999, p. 160). However, here we touch upon a very serious problem: is it possible to remove all mathematics from economic theory and still have successful economics? Most probably Prof. Malawski would claim the following: it is possible, but at the price of lowering the accuracy, precision, and range of economic insights. He would probably say this because in his view the axiomatisation of economics contributed greatly to its development.

Malawski's insights in support of the idea that economics can be axiomatised are somehow in line with various developments in twentieth-century economics. Take, for instance, the epigraph to P. Samuelson's Foundations of Economic Analysis: "Mathematics is a language". Or G. Debreu's claim that "in its mathematical form, economic theory is open to efficient scrutiny for logical errors" (Debreu 1991, p. 3). Not to mention R. Lucas's manifesto: “(...) mathematical analysis is not one of many ways of doing economic theory. It is the only way" (Warsh 2006, p. 168). Some readers may simply ask why there is such strong emphasis on the use of mathematics. Here we should refer to the philosophy that inspired people like Samuelson and Debreu. As far as Samuelson is concerned, one should note his links to key logical positivist philosophers such as R. Carnap. It was Carnap, together with $\mathrm{H}$. Hahn and O. Neurath, who famously proclaimed in their manifesto:

In science there are no "depths"; there is surface everywhere: all experience forms a complex network, which cannot always be surveyed and can often be grasped only in parts. Everything is accessible to man; and man is the measure of all things. Here is an affinity with the Sophists, not with the Platonists; with the Epicureans, not with the Pythagoreans; with all those who stand for earthly being and the here and now. The scientific world-conception knows no unsolvable riddle (Carnap, Hahn \& Neurath 1929, p. 306).

If there are no "depths", and if mathematics only can serve as something relatively unchangeable, then paradoxically we have metaphysics in economics; however, it is mathematics that plays this role. As A. Weil put it: "Metaphysics has become mathematics, and is ready to form the topic of a treatise whose cold beauty would be incapable of moving us" (Dalmedico 2001, p. 236) $)^{3}$. Nevertheless, Samuelsonian economics treats mathematics as a very special tool and is therefore similar to the Marshallian treatment of mathematics famously summarised in his maxim that "[Economists should]

${ }^{3}$ André Weil was a very influential French mathematician and a member of the so-called Bourbaki group. 
use mathematics as a shorthand language, rather than an engine of inquiry" (Marshall 1906) ${ }^{4}$. His scepticism was shared by Vilfredo Pareto (1911), who claimed that many economists wrongly imagined mathematical economics to be something capable of solving the problems of practical economics. Knowing Prof. Malawski's work, I am convinced that he would agree with this statement.

But let me now offer a different way of analysing the issue of whether the economic realm is deeply mathematical. Imagine, contrary to Prof. Malawski, that economies are mathematical like many domains analysed by physicists, and thus one can legitimately claim that in such a case mathematics alone should be able to explain economic phenomena. Is this possible? I shall attempt to answer this question below.

\section{Can Mathematics Alone Explain Economic Phenomena?}

Mathematics is widely present in economics. It is used in many kinds of explanations. However, some philosophers of science argue that mathematics alone can explain phenomena without making any references to laws, causes, etc. Thus, for instance, M. Lange (2013) claims that distinctively mathematical explanations (DME) are possible. He gives the following example:

The fact that twenty-three cannot be divided evenly by three explains why it is that mother fails every time she tries to distribute exactly twenty-three strawberries evenly among her three children without cutting any (strawberries!) (Lange 2013, p. 488).

P. Lipton (2004), on the other hand, offers the following illustration:

There also appear to be physical explanations that are non-causal. Suppose that a bunch of sticks are thrown into the air with a lot of spin so that they twirl and tumble as they fall. We freeze the scene as the sticks are in free fall and find that appreciably more of them are near the horizontal than near the vertical orientation. Why is this? The reason is that there are more ways for a stick to be the horizontal than near the vertical. To see this, consider a single stick with a fixed midpoint position. There are many ways this stick could be horizontal (spin it around in the horizontal plane), but only two

\footnotetext{
${ }^{4}$ Here is the full quotation from A. Marshall (1906, pp. 427-428): "[I had] a growing feeling in the later years of my work at the subject that a good mathematical theorem dealing with economic hypotheses was very unlikely to be good economics: and I went more and more on the rules (1) Use mathematics as a shorthand language, rather than an engine of inquiry. (2) Keep to them till you have done. (3) Translate into English. (4) Then illustrate by examples that are important in real life. (5) Burn the mathematics. (6) If you can't succeed in (4), burn (3). This last I did often”.
} 
ways it could be vertical (up or down). This asymmetry remains for positions near horizontal and vertical, as you can see if you think about the full shell traced out by the stick as it takes all possible orientations. This is a beautiful explanation for the physical distribution of the sticks, but what is doing the explaining are broadly geometrical facts that cannot be causes (Lipton 2004, pp. 9-10).

So, we have DME in a given science, say economics, once mathematics alone explains phenomena. Or, in other words, once we delete economics (e.g. references to economic laws, causes, etc.) from economic explanations and what remains is just mathematics that still explains economic phenomena, then what we have is DME in economics. Now, if one understands the above mother-strawberries example as an instance of the classic economic problem of the optimal allocation of scarce resources, then this very illustration may be treated as DME in economics. But what about cases of explanations in economics where mathematics is in place but which cannot be understood as DME? Let me give the following example. Suppose that we have a typically defined average variable cost of production, namely $A V C(y)=\frac{c_{v}(y)}{y}$ and hence the question is what is the value of $A V C(0)$ ? If $y=0$, then this expression $(0 / 0)$ is indeterminate. However, the value of the limit of $\frac{c_{v}(y)}{y}$ can be calculated using L'Hôpital's rule: $\lim _{y \rightarrow 0} \frac{c_{v}(y)}{y}=\frac{c^{\prime}(0)}{1}$. It follows that the average variable cost of production at zero output is just marginal cost (see, for instance, Varian 1992, p. 69). If we agree that L'Hôpital's rule constitutes a mathematical fact, we can assess whether this is a distinctively mathematical explanation and, bearing in mind that we are referring to economic ideas of various cost categories, my answer is that it is not.

In my 2017 book, Economics without Laws (Hardt 2017), I show that cases of DME are relatively rare in economics. In other words, mathematics alone does not offer economists much in accounting for economic phenomena. This is also true in the case of the Arrow-Debreu world where we do not have only mathematics but also references to laws, concepts, causes, etc. If instances of DME are hardly present in economics, does this prove that the economic realm is not mathematical? Well, to be honest, more research is needed to answer this question. However, one may suppose that the more mathematical a given realm, the more frequent the use of DME to account for its functioning. So, we should have more DME in physics than in economics. Prof. Malawski would probably agree, although he might 
humbly add that one may only potentially have more DME in physics. Why? Simply because one needs to have a proper mathematics in order to correctly explain various phenomena. At the very end of his 2016 paper on whether the economic world is mathematical, he cites the following paragraph from Whitehead (1964):

Having regard to the immensity of its subject-matter mathematics, even modern mathematics, is a science in its babyhood. If civilisation continues to advance, in the next two thousand years the overwhelming novelty in human thought will be the dominance of mathematical understanding" (Whitehead 1964, p. 117).

Therefore, we may have more DME in economics in the future once we achieve more advanced mathematics, but since the economic realm is not totally mathematical, it is hardly possible that mathematics alone will be able to explain economic phenomena ${ }^{5}$. But still another important issue requires our attention, namely, the issue of the nature of laws in economics. Here one may suppose that although economies are not inherently mathematical, economics is so mathematicised that it should have rather strict and strong laws. Is this right? The following section addresses this very issue.

\section{Are There Laws in Economics?}

Let us give the floor to Prof. Malawski with regard to his opinion on the nature of economic laws. In his 1999 book, he wrote:

The laws of nature are spatiotemporally universal whereas the laws of economics are historical and local. This difference is due to the fact that real systems investigated by economists are far more complex and internally integrated as well as less stable than the ones analysed in physics. Therefore, economists have problems with ceteris paribus clauses (...). At the same time, the historical variability of economic systems causes permanent lags in the formulation of economic laws (...) and hence they are of little use in

${ }^{5}$ I am aware that there are many purely philosophical problems regarding the status of DME. Let me highlight the following one, for instance. Some philosophers claim that the ontic form of the counterfactual theory of explanation cannot accommodate DME. This is so because, in ontic theories, dependencies hold between things in the world rather than between representations (see, for instance, Kuorikoski 2017). M. Lange (2013) is well aware of this problem and thus opts for more modal conceptions that show the necessity of the explanandum. I think that one can have abstract dependencies in ontic theories based on counterfactuals (cf. Reutlinger 2016). Let us, then, reformulate the mother-strawberries example in the following way: "if mother had had a number of apples evenly divisible by four, then she would not have failed to distribute her apples among her four children". Further in-depth study of these issues is definitely beyond the scope of this paper, but I would like my readers to be aware of these philosophical problems. 
the formulation of economic policies and their predicative power is less than limited (...) (Malawski 1999, pp. 165-66).

Clearly, therefore, for Prof. Malawski the laws of economics are not the same as the laws of physics. It is interesting that this view is shared by the founding fathers of modern economics. For instance, A. Marshall wrote that "the laws of economics are to be compared with the laws of the tides, rather than with the simple and exact law of gravitation" (Marshall 1920, p. 32). And commenting on the historical character of such laws he stated the following: "If the subject matter of a science passes through different phases of development, the laws of the science must have a development corresponding to the things of which they treat" (Marshall 1890, p. 65). Similarly, J. S. Mill emphasised the inexactness of economic laws; hence his well-known definition of such law-statements: "All laws of causation, in consequence of their liability to be counteracted, require to be stated in words affirmative of tendencies only, and not of actual results" (Mill 1843, p. 523). In Hardt (2017) I summarise in the following words the way classical economists understood laws of economics:

Classical economists were conscious that the laws they formulate definitely do not hold in every circumstance. Moreover, they seem to agree that the only place in which a given law is always true is in the model used to produce that very law (Hardt 2017, p. 195).

I do not claim that Smith, Ricardo, Mill, and Marshall used models as contemporary economists do. However, they had their model words. Smith talked about little imaginary machines that thinkers use while investigating the way the world works. Ricardo is famous for the models employed in his theories of comparative advantage and rent. Mill offered economics notions of abstract truth and truth in the concrete; he thus wrote: "the conclusions correctly deduced from these assumptions, would be as true in the abstract as those of mathematics; and would be as near an approximation as abstract truth can ever be, to truth in the concrete" (Mill 1836, p. 49). And what about Marshall? He was very mechanistic in his world view, at least at the beginning of his research career, and for him economies resembled machines. One could therefore investigate them by building mechanistic pictures of them, namely, models. In Marshall's words: “(...) it is worthwhile to reduce the processes to system and to erect the machinery of science in order to deal with them" (Marshall 1890, p. 88). So, the modelling method is at the very heart of economics, and from the outset classical economists did not believe in the pure universality of economic laws. 
But what if economic phenomena are not reducible to their parts and are just the emergent effects of underlying processes? Or, to put it another way, what if economic causes react chemically rather than mechanically? Both Marshall and Mill were conscious of this very fact. And thus Marshall had a dream to write the second part of his Principles offering a vision of economics based on biology. Consequently, he famously claimed that "the Mecca of the economist is economic biology rather than economic dynamics" (Marshall 1898, p. 43). And similarly Mill stated that when economic causes interact chemically one cannot use the method of isolation, and thus formulating laws of economics with the same lawhood as Newtonian laws of physics would be simply impossible. Interestingly, we find similar insights in Prof. Malawski's attempts to unify (and axiomatise) Schumpeterian evolutionary theory. For him, evolution is possible only when one subscribes to a very special kind of world ontology, precisely one which treats the world as always being dynamically in statu nascandi. In such a world, any spatiotemporally universal constant conjunctions are simply impossible. Therefore, Prof. Malawski's work on the mathematisation of various aspects of evolutionary economics resembles, at least to some extent, the research done by his great predecessors.

Let me return, however, to the mechanistic models economics uses and ask what is the nature of the knowledge they produce, or, to put it differently, how one should understand relations in the triad: models-theoriesempirical phenomena? Firstly, models may be conceptualised as entities producing theories. Take, for instance, the celebrated checkerboard model by Schelling and its product, namely, the insightful claim that even without a strong preference for segregation people will strongly self-segregate. Secondly, these models' claims are statements of tendencies only. So, in the context of Schelling's model, one should only say that people will tend to self-segregate. Thirdly, as far as empirical phenomena are concerned, one does not test the validity of a given model as such, but rather the claims produced by the model in question. As F. Guala rightly points out: "The fact that a model turns out not to work under certain circumstances does not count as a refutation of the model but only as a failed test of its applicability in a given domain" (Guala 2005, p. 220). Models should resemble the realities they refer to. Next, tendency laws produced by models may be understood in an ontologically rich manner, namely, as sentences describing what is in the nature of a given entity to produce. Now, for instance, rather than claiming that lower interest rates will produce a tendency for investments to rise, one should just say that it is in the nature of lower interest rates to 
stimulate investments ${ }^{6}$. Similarly, a typical ceteris paribus clause should be supplemented by a ceteris normalibus reservation. Hence we are in a very Aristotelian world.

To conclude, let us once again return to Prof. Malawski's words from the final chapter of his 1999 book:

Differential equations constitute the language in which the laws of physics are formulated. Similar attempts were undertaken in the social sciences and in economics, such as in the works of A. Cournot and L. Walras and in the contemporary works of P. Samuelson and R. Lucas. However, one cannot assess them as satisfactory - differential equations failed to form the language of the social sciences and economics; and, even more so, a strict and general language for formulating such laws does not exist. The reason for this lies in the great complexity of social and economic systems as compared with natural ones (Malawski 1999, p. 178).

Most probably, the postulated nonexistence of strict language may be understood as Prof. Malawski's refusal to view the socio-economic world through mechanistic ontology. Nevertheless, his conviction that universal laws are not possible in economics is beyond doubt.

\section{Conclusions}

After the above short reflection on Prof. Malawski's thinking on economics, mathematics, and philosophy, one might ask where lies the key to interpreting his way of analysing the world. What I believe is that this key may be found in Prof. Malawski's humility: he was not only a humble person, but his science was a humble science - we are able to know much, but our knowledge will never be free of doubt. He was well aware that there is mystery in the world. As L. Kołakowski wisely put it many years ago: "But although we cannot pierce the mystery and convert it into knowledge, our awareness that there is mystery is in itself important; although we cannot tear the veil from ultimate reality, we should know that such a veil exists" (Kołakowski 2001, p. 10). And for Prof. Malawski the very existence of this mystery is somehow connected to ontological uncertainty about the foundations of the socio-economic realm. Why uncertainty? Simply because the old Newtonian mechanistic ontology is no longer valid, and Prof. Malawski, as an economist interested in evolutionary economics, was deeply conscious of this fact. In a sense, his work may be treated as a search for a "post-mechanistic" and metaphysically rich paradigm. Prof. Malawski

\footnotetext{
| $\quad{ }^{6}$ I develop such a vision of economic laws in Hardt (2017).
} 
surely belonged to that very special group of scientists described by P. Davies and J. Gribbin as follows:

In all these areas scientists have found it fruitful, or even essential, to regard the portion of the universe they are studying in entirely new terms, terms that bear little relation to the old ideas of materialism and the cosmic machine. This monumental paradigm shift is bringing with it a new perspective on human beings and their role in the great drama of nature (Davies \& Gribbin 1992, p. 8).

Thus, Prof. Malawski's work was at once intellectually elegant, philosophically rich, and revealed not only his sound knowledge of economics but also his desire to influence economic theory. Last but not least, he tried to persuade to do economics in a humble way; hence his denial of the existence of universal laws of economics combined with his refutation of the possibility that the depths of the economic realm can be purely mathematical. I hope that this special issue of Argumenta Oeconomica Cracoviensia will help the Polish community of economists to rediscover Prof. Malawski's works and in particular his 1999 book - The Axiomatic Method in Economics.

\section{Bibliography}

Carnap, R., Hahn, H. and Neurath, O. (1929) "The Scientific Conception of the World: The Vienna Circle" in M. Neurath and R. S. Cohen (eds) Otto Neurath: Empiricism and Sociology. Dordrecht-Boston 1973: D. Reidel Publishing Company, pp. 299-319.

Colyvan, M. (2015) "Indispensability Arguments in the Philosophy of Mathematics" in E. N. Zalta (ed.) The Stanford Encyclopedia of Philosophy Archive (Spring 2015 Edition), https://plato.stanford.edu/archives/spr2015/entries/mathphil-indis/ (accessed: 1 February 2018).

Dalmedico, A. D. (2001) "An Image Conflict in Mathematics after 1945" in U. Bottazzini and A. D. Dalmedico (eds) Changing Images in Mathematics: From the French Revolution to the New Millennium. London: Routledge, pp. 223-54.

Davies, P. and Gribbin, J. (1992) The Matter Myth. London: Penguin Books.

Debreu, G. (1991) "The Mathematization of Economic Theory". American Economic Review 81 (1): 1-7.

Decock, L. (2002) “Quine's Weak and Strong Indispensability Argument”. Journal for General Philosophy of Science 33 (2): 231-50, https://doi.org/10.1023/a:1022471707916.

Field, H. H. (1980) Science Without Numbers: A Defence of Nominalism. Oxford: Blackwell.

Guala, F. (2005) The Methodology of Experimental Economics. Cambridge: Cambridge University Press. 
Hardt, Ł. (2017) Economics without Laws. Towards a New Philosophy of Economics. Cham, Switzerland: Palgrave Macmillan.

Jevons, W. S. (1879) The Theory of Political Economy. London: Macmillan and Co.

Kitcher, P. (1984) The Nature of Mathematical Knowledge. New York: Oxford University Press.

Kołakowski, L. (2001) Metaphysical Horror. Chicago: University of Chicago Press.

Kuorikoski, J. (2017) "There Are No Mathematical Explanations". Unpublished manuscript, University of Helsinki.

Lange, M. (2013) "What Makes a Scientific Explanation Distinctively Mathematical?". British Journal for the Philosophy of Sciences 64 (3): 485-511, https://doi.org/10.1093/ bjps/axs012.

Lipton, P. (2004) "What Good Is an Explanation” in J. Cornwell (ed.) Explanations. Styles of Explanation in Science. Oxford: Oxford University Press, pp. 1-21.

Malawski, A. (1999) Metoda aksjomatyczna $w$ ekonomii [The axiomatic method in economics]. Kraków: Ossolineum.

Malawski, A. (2016) "Matematyzacja ekonomii: matematyczność czy matematyzowalność rzeczywistości gospodarczej" [The mathematisation of economics: mathematicalness or mathematicability of economic reality?] in M. Gorazda, Ł. Hardt and T. Kwarciński (eds) Metaekonomia. Zagadnienia z filozofii ekonomii [Metaeconomics. Problems of economic philosophy]. Kraków: CC Press, pp. 131-58.

Marshall, A. (1890) Principles of Economics. First edition. London: Macmillan.

Marshall, A. (1898) "Distribution and Exchange". Economic Journal 8 (29): 37-59, https://doi.org/10.2307/2956696.

Marshall, A. (1906) "Letter to Bowley from February 27, 1906" in A. C. Pigou (ed.) Memorials of Alfred Marshall. New York 1966: A. M. Kelley, pp. 427-28.

Marshall, A. (1920) Principles of Economics. Eighth edition. London: Macmillan.

Mill, J. S. (1836) "On the Definition and Method of Political Economy" in D. Hausman (ed.) The Philosophy of Economics. Cambridge 2008: Cambridge University Press, pp. 41-58.

Mill, J. S. (1843) A System of Logic. Ratiocinative and Inductive. London: John W. Parker.

Mirowski, P. (2012) "The Unreasonable Efficacy of Mathematics in Modern Economics" in U. Mäki, D. M. Gabbay, P. Thagard, and J. Woods (eds) Philosophy of Economics. Amsterdam: North Holland, pp. 159-97.

Pabjan, T. (2011) “Józefa Życińskiego koncepcja pola racjonalności” [Joseph Życiński's idea of the field of rationality]. Filozofia Nauki 19 (2): 7-18.

Pareto, V. (1911) "Economie Mathématique" in Encyclopédie des Sciences Mathématiques. Volume IV. Paris: Gauthier-Villars.

Putnam, H. (1979) Mathematics, Matter, and Method. New York: Cambridge University Press.

Quine, W. V. (1986) "Reply to Charles Parsons" in L. Hahn and P. Schilpp (eds) The Philosophy of W. V. Quine. La Salle: Open Court, pp. 396-403.

Reutlinger, A. (2016) "Does the Counterfactual Theory of Explanation Apply to Non-Causal Explanations in Metaphysics?". European Journal for Philosophy of Science 7: 239-56, https://doi.org/10.1007/s13194-016-0155-z.

Varian, H. R. (1992) Microeconomic Analysis. New York: W.W. Norton\&Company.

Warsh, D. (2006) Knowledge and the Wealth of Nations. New York: Norton.

Whitehead, A. N. (1964) Science and Philosophy. Paterson NJ: Littlefield, Adams \& Co. 


\section{Abstract}

\section{Refleksje na temat poglądów prof. A. Malawskiego na związki między ekonomią, matematyką i filozofią}

W artykule podjęto rozważania na temat sposobu rozumienia przez prof. A. Malawskiego związków pomiędzy ekonomią, matematyką i filozofią. W szczególności analizie poddano kwestię matematyczności gospodarki, a także tego, jak należy rozumieć ekonomię traktowaną jako naukę matematyczną. Podjęto także problematykę natury praw ekonomicznych. Artykuł kończy się stwierdzeniem, że kluczem interpretacyjnym do badań prof. A. Malawskiego jest jego wyjątkowa pokora.

Słowa kluczowe: A. Malawski, filozofia ekonomii, matematyczność ekonomii, prawa i modele w ekonomii. 